\title{
Epidemiological situation of bovine tuberculosis in the state of Tocantins, Brazil
}

\section{Situação epidemiológica da tuberculose bovina no estado de Tocantins, Brasil}

\author{
José Soares Ferreira Neto ${ }^{1 *}$; Regina Gonçalves Barbosa2; Fernando Ferreira'; \\ Marcos Amaku3; Ricardo Augusto Dias'; José Henrique Hildebrand Grisi-Filho4; \\ Vitor Salvador Picão Gonçalves ${ }^{5}$; Oswaldo Santos Baquero4; \\ Saulo de Tarso Zacarias Machado ${ }^{6}$; Evelise Oliveira Telles ${ }^{1}$
}

\section{Highlights}

Bovine Tuberculosis prevalence of infected herds in the state of Tocantins. Bovine Tuberculosis prevalence of positive animals in the state of Tocantins. The best strategy for the state is to implement eradication strategies.

\begin{abstract}
The epidemiological situation of bovine tuberculosis was studied from October 2014 to August 2015 in the state of Tocantins, a traditional beef exporter. The state was divided into five regions and the farms were randomly selected in each region. A predetermined number of animals was randomly selected and diagnosed using the Comparative Cervical Tuberculin Test. A total of 11,926 animals from 757 farms were tested. Animals with inconclusive test results were retested with the same diagnostic procedure at least 60 days later. The prevalence of infected herds in the state was $0.16 \%$ [0.02-1.15] and the prevalence of infected animals $0.009 \%$ [0.001-0.063]. Only one positive animal was detected in the Araguaína region. The state of Tocantins has a very low prevalence of bovine tuberculosis and, therefore, should evaluate the need of structuring a surveillance system to eradicate the disease.
\end{abstract}

Key words: Bovine tuberculosis. Brazil. Prevalence. Tocantins.

1 Full Profs., Faculty of Veterinary Medicine and Animal Science, University of São Paulo, FMVZ-USP, São Paulo, SP, Brazil. E-mail: jsoares@usp.br; ffernando@usp.br; bufalo@usp.br

2 Veterinary, Agricultural Health Agency of the State of Tocantins, ADAPEC, Palmas, TO, Brazil. E-mail: r.g.barbosa@ hotmail.com

${ }^{3}$ Associate Profs., Faculty of Veterinary Medicine and Animal Science, University of São Paulo, FMVZ-USP, São Paulo, SP, Brazil. E-mail: amaku@usp.br; ricardodias@usp.br

${ }^{4}$ Assistant Profs., DVM, Faculty of Veterinary Medicine and Animal Science, University of São Paulo, FMVZ-USP, São Paulo, SP, Brazil. E-mail: jgrisi@usp.br; baquero@usp.br

${ }^{5}$ Associate Prof., Faculty of Agronomy and Veterinary Medicine, University of Brasília, FAV-UNB, Brasília, DF, Brazil. E-mail: vitorspg@unb.br

${ }^{6}$ Doctoral Student of the Experimental and Applied Epidemiology to Zoonoses Program, FMVZ-USP, São Paulo, SP, Brazil. E-mail: machado_saulo@hotmail.com

* Author for correspondence

Received: Sept. 17, 2020 - Approved: Dec. 14, 2020 


\section{Resumo}

Entre outubro de 2014 a agosto de 2015, foi estudada a situação epidemiológica da tuberculose bovina no estado de Tocantins, tradicional exportador de carne. O estado foi estratificado em cinco regiões. Em cada região, propriedades foram sorteadas aleatoriamente e, dentro dessas, escolheu-se de forma também aleatória um número pré-estabelecido de animais, os quais foram submetidos ao teste tuberculínico Cervical Comparativo. No total, foram testados 11.926 animais, provenientes de 757 propriedades. Os animais que resultaram inconclusivos foram retestados com o mesmo procedimento diagnóstico em intervalo mínimo de 60 dias. No Estado, a prevalência de focos foi de 0,16\% [0,02-1,15] e a de animais 0,009\% [0,001-0,063]. Foi detectado apenas um animal positivo em propriedade da região de Araguaína. O estado de Tocantins apresenta baixíssima prevalência de tuberculose bovina e, portanto, deve avaliar a conveniência de estruturar sistema de vigilância visando à erradicação da doença.

Palavras-chave: Brasil. Prevalência. Tocantins. Tuberculose bovina.

\section{Introduction}

Mycobacterium bovis is the etiologic agent of bovine tuberculosis (bTB), a chronic zoonotic disease that also affects other domestic production and companion animals, as well as captive and free-living wild species (World Organization For Animal Health [OIE], 2018). In cattle, the main gateway is the airway, resulting in granulomatous lesions notably in the lungs and lymph nodes. Depending on the evolution of the host-parasite relationship, the disease can spread and reach any organs or tissues of the host (Domingo, Vidal, \& Marco, 2014; O'Reilly \& Daborn, 1995; Pollock, Rodgers, Welsh, \& Mcnair, 2006).

Due to its importance for public health and also for causing economic losses in the beef and milk supply chains, countries with an organized livestock production implement national bTB control and eradication programs (Acha \& Zyfres, 2001; Cosivi et al., 1999; Moda, Daborn, Grange, \& Cosivi, 1996).

In South America, the epidemiological situation of bovine tuberculosis is adequately characterized only in Uruguay, Chile, Argentina and Brazil. Uruguay is running eradication strategies and the prevalence is very low. Chile and Argentina are operating surveillance systems, but prevalence is still high in Chile and in some regions of Argentina (Ferreira, 2018).

In 2001, the Brazilian Ministry of Agriculture, Livestock and Food Supply (Ministério da Agricultura, Pecuária e Abastecimento - MAPA) launched the National Program for the Control and Eradication of Animal Brucellosis and Tuberculosis (Programa Nacional de Controle e Erradicação da Brucelose e Tuberculose Animal - PNCEBT), aimed at reducing the impact of the disease on animal and human health and at improving the sanitary status of beef and dairy cattle production chains in Brazil (Lage et al., 2006).

Some studies were initiated as part of this process, aiming at the epidemiological characterization of bTB in all Federative Units in Brazil. To date, these studies were completed in the 13 units that hold $75 \%$ of the Brazilian cattle herd (Figure 1) (Bahiense et al., 2016; Barbieri et al., 2016; Dias et al., 2016; Galvis et al., 2016; Guedes et al., 2016; Lima et al., 2016; Néspoli et al., 2016; Queiroz et al., 2016; Ribeiro et al., 2016; Rocha et al., 2016; Silva et al., 2016; Veloso et al., 2016; Vendrame et al., 2016). 
Figure 1 shows the highest prevalence in Espírito Santo, northern São Paulo, southern Minas Gerais, and southeast Goiás, the Brazilian dairy belt. Risk factor studies showed that bTB in Brazil is more concentrated in dairy herds with sophisticated production system and larger number of animals (Ferreira Neto et al., 2016). The lowest prevalence was found in regions with traditional extensive beef production system (Figure 1).

The state of Tocantins has a cattle herd of 8.8 million head and exports USD 162 million per year in meat, which means
$20 \%$ of total exports in the state (Instituto Brasileiro de Geografia e Bioestatística [IBGE], (2019), Secretaria da Agricultura, Pecuária e Aquicultura do Estado de Tocantins [SEAGRO], 2016).

Considering the importance of cattle raising for the state of Tocantins and the lack of data on the situation of bovine tuberculosis in the territory, the objective of this study was to estimate the prevalence of infected herds and positive animals in the state of Tocantins, respecting its regional characteristics.

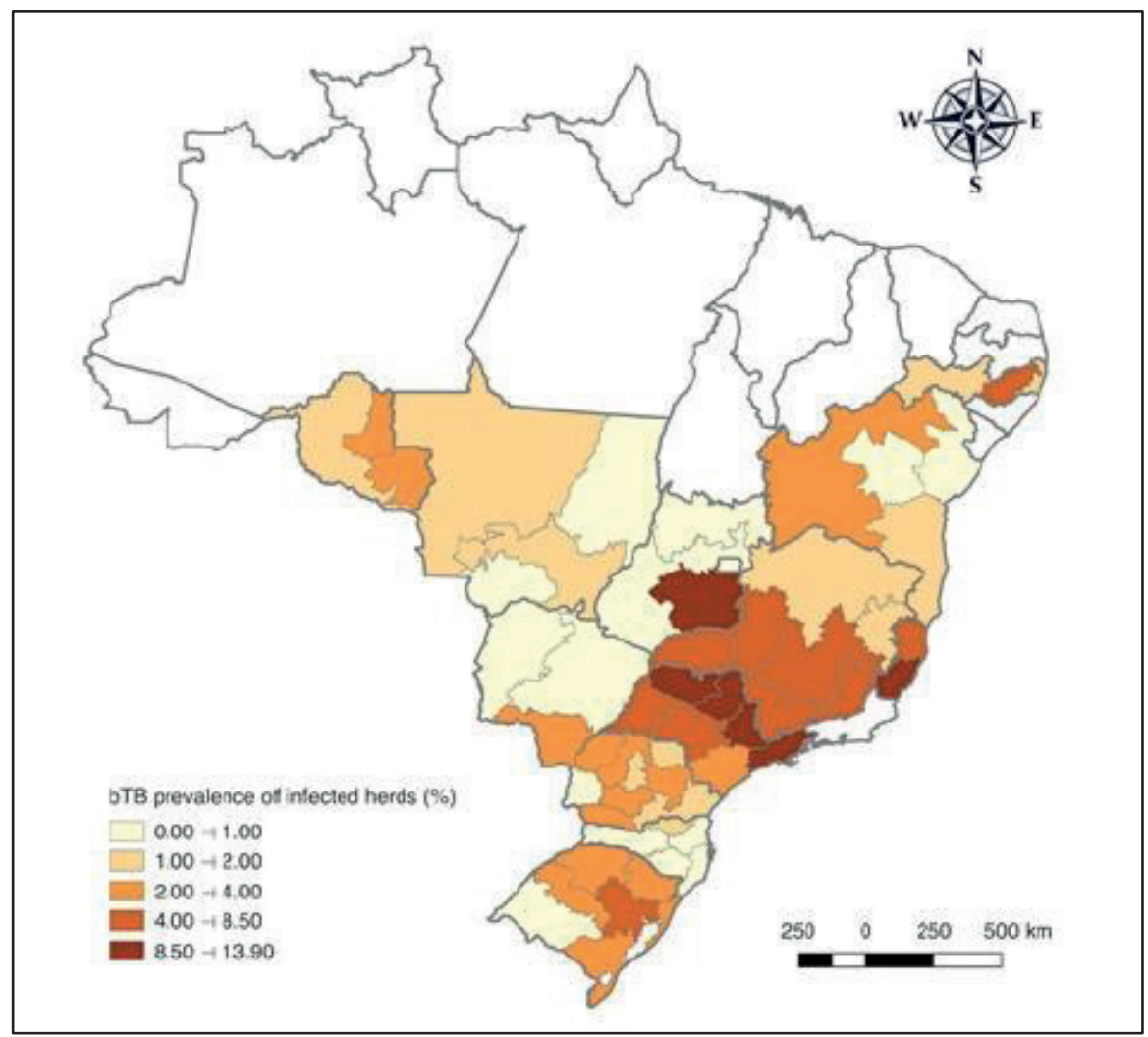

Figure 1. Prevalence of bovine tuberculosis infected herds in Brazil. Source: Ferreira Neto et al., 2016. 


\section{Material and Methods}

This study was planned by technicians from MAPA, the Collaborating Center on Animal Health of the School of Veterinary Medicine and Animal Science of the University of São Paulo (FMVZ-USP) and from the Oficial Veterinary Service of the State of Tocantins (Agência de Defesa Agropecuária do estado de Tocantins - ADAPEC), being the latter responsible for the fieldwork from October 2014 to August 2015.

The state was divided into regions, considering different production systems, management practices, type of exploitation, mean herd size, animal marketing system and animal health defense operational capacity.

A predetermined number of farms with reproductive activity (primary sampling units) was randomly chosen within each of these regions. This process used the farm register maintained by ADAPEC. Then, a predetermined number of female cows aged 24 months or older (secondary sampling units) was randomly chosen within each selected farm.

In the farms where there were more than one herd, the most economically important herd was chosen in order to analyze animals raised under the same management, that is, under the same risks of exposure to infection. If for any reasons the farm selected could not be visited, another farm was chosen. The number of farms selected by region was estimated by the simple random sampling formula (Thrusfield \& Christley, 2018). The parameters used to meet the operational capacity of the state were: 0.95 confidence level, estimated prevalence of 0.10 , and error of 0.05 .

A minimum number of animals to be examined in each farm was calculated to classify them as infected herds or tuberculosisfree, using aggregate sensitivity of $85 \%$ or greater and aggregate specificity of $95 \%$ or greater. Individual sensitivity and specificity values were $80 \%$ and $99.5 \%$, respectively. The Herdacc version 3.0 software was used for the calculations.

The animals were diagnosed using the comparative cervical tuberculin skin test, with suspected animals being retested at least 60 days after. These procedures follow the PNCEBT Technical Manual (Lage et al, 2006). Tuberculin-positive animals were euthanized.

The prevalence of infected herds and animals were obtained for each region and also for the state. Apparent prevalence and the respective confidence intervals were calculated as recommended by Dean et al. (1996). Infected herds and animal prevalence in the state and animal prevalence in the regions were weighted (Dohoo, Martin, \& Stryhn, 2012). The weight of each farm to calculate prevalence of infected herds in the state was given by:

$$
P_{1}=\frac{\text { Farms with reproductive activity in the region }}{\text { Farms with reproductive activity sampled in the region }}
$$

The weight of each animal to calculate animal prevalence in the state was given by:

$P_{2}=\frac{\text { Females } \geq 24 \text { months in the farm }}{\text { Females } \geq 24 \text { months sampled in the farm }} \times \frac{\text { Females } \geq 24 \text { months in the region }}{\text { Females } \geq 24 \text { months sampled in the region }}$


In the formula above, the first term refers to the weight of each animal to calculate the prevalence in animals in each region. The SPSS version 20 software was used for these calculations.

Fieldwork information was entered into a specific database used for epidemiological analyses at the FMVZ-USP Laboratory of Epidemiology and Biostatistics (LEB).

\section{Results and Discussion}

The state was divided into five regions, as shown in Figure 2. The census and sample data of this study are shown in Table 1 and the results of animal and infected herds prevalence in Table 2. The initial plan was to analyze risk factors, but it was not possible because only one infected herd was identified in the Araguaína region (Table 2).
Considering only the specific results of estimated infected herds $(0.16 \%)$ and animal $(0.009 \%)$ prevalence (Table 2$)$, the state of Tocantins presented the lowest values among the Federative Units studied to date (Bahia [BA], Minas Gerais [MG], São Paulo [SP], Espírito Santo [ES], Mato Grosso do Sul [MS], Mato Grosso [MT], Pernambuco [PE], Rio Grande do Sul [RS], Distrito Federal [DF], Goiás [GO], Paraná $[P R]$, Santa Catarina [SC] and Rondônia [RO]). However, as for confidence intervals, Tocantins had the same prevalence of infected herds as the states of MT, MS, SC, BA and DF (Néspoli et al., 2016; Guedes et al., 2016; Veloso et al., 2016; Bahiense et al., 2016; Ribeiro et al., 2016) and smaller than the states of MG, SP, PR, RS, ES, PE, GO and RO (Barbieri et al., 2016; Dias et al., 2016; Silva et al., 2016; Queiroz et al., 2016; Galvis et al., 2016; Lima et al., 2016; Rocha et al., 2016; Vendrame et al., 2016).

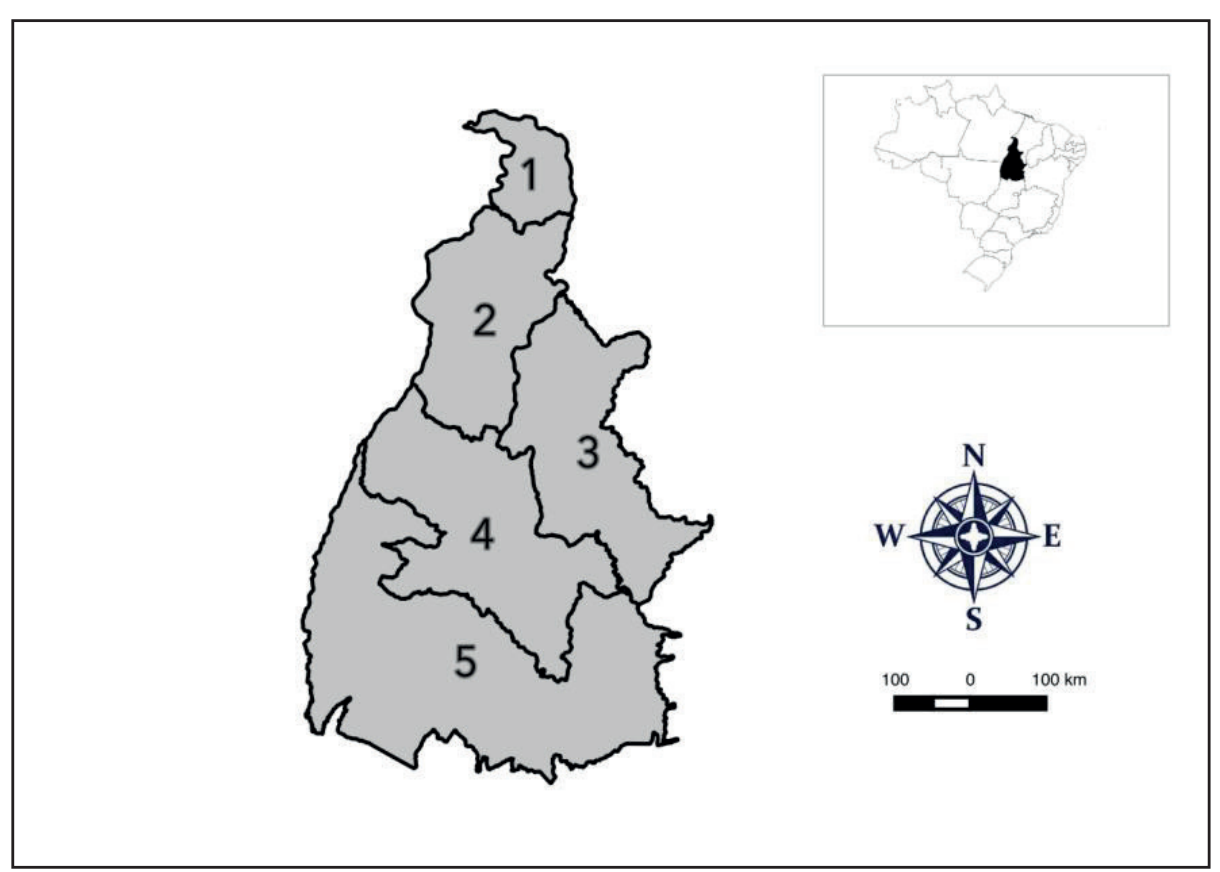

Figure 2. Map of the state of Tocantins showing the study regions: 1) Bico do Papagaio, 2) Araguaína, 3) Jalapão, 4) Central, and 5) Sul. In the detail, the location of the Federative Unit in Brazil. 
Table 1

Census and sampling data of the study of bovine tuberculosis in the state of Tocantins, Brazil

\begin{tabular}{|c|c|c|c|c|c|}
\hline $\begin{array}{l}\text { region } \\
\text { number }\end{array}$ & $\begin{array}{l}\text { region } \\
\text { name }\end{array}$ & $\begin{array}{l}\text { number of } \\
\text { herds with } \\
\text { reproductive } \\
\text { activity }\end{array}$ & $\begin{array}{c}\text { number of } \\
\text { females aged } \geq \\
24 \text { months }\end{array}$ & $\begin{array}{c}\text { number of } \\
\text { sampled herds }\end{array}$ & $\begin{array}{c}\text { number of } \\
\text { females aged } \\
\geq 24 \text { months } \\
\text { sampled }\end{array}$ \\
\hline 1 & Bico do Papagaio & 6.685 & 289.211 & 151 & 1.328 \\
\hline 2 & Araguaína & 13.225 & 839.205 & 151 & 1.351 \\
\hline 3 & Jalapão & 5.725 & 227.460 & 151 & 1.326 \\
\hline 4 & Central & 13.128 & 845.629 & 153 & 1.399 \\
\hline \multirow[t]{2}{*}{5} & Sul & 15.256 & 1.276 .413 & 150 & 1.442 \\
\hline & Total & 54.019 & 3.477 .918 & 756 & 6.846 \\
\hline
\end{tabular}

Source: unpublished data from the Official Veterinary Service of the State of Tocantins (Agência de Defesa Agropecuária do estado de Tocantis [ADAPEC]).

Table 2

Prevalence of bovine tuberculosis positive animals and infected herds in the state of Tocantins, Brazil

\begin{tabular}{ccccccccc} 
& \multicolumn{3}{c}{ animals } & \multicolumn{5}{c|}{ herds } \\
\cline { 2 - 8 } Region & tested & positive & $\begin{array}{c}\text { prevalence } \\
(\%)\end{array}$ & Cl 95\% (\%) & tested & positive & $\begin{array}{c}\text { prevalence } \\
(\%)\end{array}$ & Cl 95\% (\%) \\
\hline 1 & 2115 & 0 & 0 & - & 151 & 0 & 0 & $0-1.95$ \\
2 & 2352 & 1 & 0.037 & $0.005-0.268$ & 151 & 1 & 0.662 & $0.091-4.65$ \\
3 & 2262 & 0 & 0 & - & 151 & 0 & 0 & $0-1.95$ \\
4 & 2536 & 0 & 0 & - & 154 & 0 & 0 & $0-1.91$ \\
5 & 2661 & 0 & 0 & - & 150 & 0 & 0 & $0-1.96$ \\
Total & 11926 & 1 & 0.009 & $0.001-0.063$ & 757 & 1 & 0.162 & $0.023-1.15$
\end{tabular}

For herds, if the numerator was zero, the Confidence Interval was calculated by $\beta$ distribution and Monte Carlo's simulation. 
As for animal prevalence, the states of MG, SP, RS, ES, PE and GO corroborated the results for infected herds prevalence and also showed higher values than the state of Tocantins (Barbieri et al., 2016; Dias et al., 2016; Queiroz et al., 2016; Galvis et al., 2016; Lima et al., 2016; Rocha et al., 2016). Similar reasoning can be applied to the states of MS, MT, SC and DF, which presented animal prevalence equal to the state of Tocantins (Néspoli et al., 2016; Guedes et al., 2016; Veloso et al., 2016; Ribeiro et al., 2016).

The states of PR and RO, although with a higher infected herds prevalence than Tocantins, showed equal animal prevalence, highlighting that the animal prevalence in RO (CI95\%: $0.06-0.25$ ) is within the limit of statistical significance when compared to Tocantins (Cl95\%: 0.001 - 0.063) (Silva et al., 2016; Vendrame et al., 2016). An opposite situation was found in BA, which had a similar prevalence of infected herds and higher of animals (Cl95\%: 0.07 - 0.6) than in Tocantins, although also within the limit of statistical significance (Bahiense et al., 2016).

Considering the results for the entire bovine population of the state, Tocantins presents between 12 and 621 infected herds of bovine tuberculosis (most likely value $=86$ ) and between 35 and 2,191 tuberculin-positive cows (most likely value $=313$ ). Since the price of a calving cow in the city of Araguaína on 29/10/2019 was BRL 2,000.00 (https://www. norteagropecuario.com.br/cotações/) and the upper limit of the confidence interval to estimate animal prevalence $(2,191)$, the total spending on animal replacement to eradicate the disease would be at the most BRL $4,382,177.00$ (most likely = BRL 626,025.00).

However, considering the low prevalence in the state of Tocantins, the cost of animal replacement is low since few animals are infected. What involves great effort and cost is finding these few infected herds and infected animals. The best way to do this is by implementing a surveillance system to detect and treat residual infected herds in order to eradicate the disease.

For bovine tuberculosis, the OIE (2019) recommends tracking infected herds through the detection of lesions in slaughterhouses and laboratory confirmation of the etiology of the lesion (M. bovis) as the basis for a surveillance system in eradication areas. In Brazil, it is extremely important that slaughterhouses under state and municipal inspection collect and send lesions for direct laboratory diagnosis, since most discarded dairy animals are slaughtered in this network and bovine tuberculosis in Brazil is more concentrated in the dairy herd (Ferreira Neto et al., 2016).

In spite of the fact that it was not possible to study risk factors for bTB in Tocantins, but considering that in Brazil the disease is more frequent in dairy herds under sophisticated production systems and with a larger number of animals (Ferreira Neto et al., 2016), a possible second component could be the active search for tuberculosis infected herds in this type of farm using the tuberculin skin test.

A third component could be the screening of infected herds using the routine tuberculin tests already required for the movement of animals in Brazil. This would require the Official Veterinary Service to carry out tuberculin tests in the herds of origin of the animals positive to the tests performed for the purpose of movement.

A fourth component could be the screening of infected herds by diagnosing 
human tuberculosis in patients who live in rural areas and work in livestock. This component would require an interface with the public health system, communicating to the Official Veterinary Services the cases of human tuberculosis in individuals working in the cattle sector, so that tuberculin tests could be performed on these farms.

Bearing in mind that the surveillance systems hardly reach all the farms, a fifth component could be the active search of infected herds through cross-sectional studies in groups of farms not reached by the components used. This would be the only strategy capable of reaching properties that do not slaughter animals in structures with a carcass inspection service, that do not carry out tuberculin tests before moving animals and that do not have workers diagnosed with tuberculosis.

A sixth component for detecting bTB-infected herds could be upstream and downstream research or analysis of epidemiological links from any infected herds identified by the previous components. For example, whenever an bTB-infected infected herd was detected from the slaughterhouse inspection service, the tuberculin test would be carried out on farms that have sold and bought animals from it in the past 24 months.

The six components mentioned above include all possibilities to rationally detect bTB infected herds. The state of Tocantins will have to evaluate which ones are best suited for its production system and operating capacity, initially choosing few components and gradually, through continuous system evaluation, refining the detection system and eventually incorporating other infected herds detection strategies (Callefe \& Ferreira, 2020).

\section{Conclusions}

The state of Tocantins has a very low prevalence of herds and animals infected with bTB and, therefore, should evaluate the convenience of a surveillance system aimed at eradicating the disease.

\section{Acknowledgements}

The authors thank the financial support of the MAPA, the ADAPEC, the CAPES - Finance Code 001, and Fapesp (Public Policy Process 2017/50190-1).

\section{References}

Acha, P., \& Zyfres, B. (2001). Tuberculosis zoonótica. In P. Acha, \& B. Zyfres, Zoonosis $y$ enfermedades transmisibles comunes al hombre y a los animales (pp. 266283). Washington, DC: Organización Panamericana de la Salud-OMS. Retrieved from https://www.paho.org/hq/ dmdocuments/2017/Acha-Zoonosis-Spa. pdf

Bahiense, L., Ávila, L. N., Bavia, M. E., Amaku, M., Dias, R. A., Grisi, J. H. H., Fo,... Ferreira Neto, J. S. (2016). Prevalence and risk factors for bovine tuberculosis in the State of Bahia, Brazil. Semina: Ciências Agrárias, 37(5, Suppl. 2), 3549-3560. doi: 5433/1679-0359.2016v37n5Supl2p3549

Barbieri, J. M., Oliveira, L. F., Dorneles, E. M. S., Mota, A. L. A. A., Gonçalves, V. S. P., Maluf, P. P.,... Lage, A. P. (2016). Epidemiological status of bovine tuberculosis in the state of Minas Gerais, Brazil. Semina: Ciências Agrárias, 37(5, Suppl. 2), 3531-3548. doi: 5433/1679-0359.2016v37n5Supl2p3531 
Callefe, J. L. R., \& Ferreira Neto, J. S. (2020). Sistemas de vigilância em saúde animal. São Paulo, SP: Faculdade de Medicina Veterinária e Zootecnia da Universidade de São Paulo.

Cosivi, O., Grange, J. M., Daborn, C. J., Raviglione, M. C., Fujikura, T., Cousins, D.,... Meslin, F. X. (1999). Zoonotic tuberculosis due to Mycobacterium bovis in developing countries. Emerging Infectious Diseases, 4(1), 59-70. doi: 10.3201/eid0401.980108

Dean, A. G., Dean, J. A., Coulombier, D., Brendel, K. A., Smith, D. C., Burton, A. H.,... Arner, T. G. (1996). Epi Info, version 6: a word processing, database, and statistics program for public health on IBM-compatible microcomputers. Atlanta, Georgia: Centers for Disease Control and Prevention. Retrieved from http:// www.epiinformatics.com/ADPublications/ El603Man.pdf

Dias, R. A., Stanojlovic, F. M. U., Belchior, A. P. C., Ferreira, R. S., Gonçalves, R. C., Aguiar, R. S. C. B.,... Ferreira Neto, J. S. (2016). Prevalence and risk factors for bovine tuberculosis in the state of São Paulo, Brazil. Semina: Ciências Agrárias, 37(5, Suppl. 2), 3673-3684. doi: 10.5433/16790359.2016v37n5 Supl2p3673

Dohoo, I., Martin, W., \& Stryhn, H. (2012). Methods in epidemiologic research. Charlottetown, Prince Edward Island: VER Inc.

Domingo, M., Vidal, E., \& Marco, A. (2014). Pathology of bovine tuberculosis. Research in Veterinary Science, 97(Suppl.), S20-S29. doi: 10.1016/j.rvsc.2014.03.017

Ferreira Neto, J. S. (2018). Brucellosis and tuberculosis in cattle in South America.
Brazilian Journal of Veterinary Research and Animal Science, 55(2), 1-23. doi: 10.11606/ issn.1678-4456.bjvras.2018.141139

Ferreira Neto, J. S., Silveira, G. B., Rosa, B. M., Gonçalves, V. S. P., Grisi, J. H. H., $F^{\circ}$., Amaku, M.,... Lage, A. P. (2016). Analysis of 15 years of the national program for the control and eradication of animal brucellosis and tuberculosis, Brazil. Semina: Ciências Agrárias, 37(5, Suppl. 2), 3385-3402. doi: 10.54 33/1679-0359.2016v37n5Supl2p3385

Galvis, J. O. A., Grisi, J. H. H., Fo., Costa, D., Ribeiro Said, A. L. P., Amaku, M., Dias, R. A.,... Ferreira Neto, J. S. (2016). Epidemiologic characterization of bovine tuberculosis in the State of Espírito Santo, Brazil. Semina: Ciências Agrárias, 37(5, Suppl. 2), 3567-3578. doi: 10.5433/16790359.2016v37n5Supl2p3567

Guedes, I. B., Bottene, I. F. N., Monteiro, L. A. R. C., Leal, J. M., Fo., Heinemann, M. B., Amaku, M.,... Ferreira Neto, J. S. (2016). Prevalence and risk factors for bovine tuberculosis in the state of Mato Grosso do Sul, Brazil. Semina: Ciências Agrárias, 37(5, Suppl. 2), 3579-3588. doi: 10.5433/1679-0359. 2016v37n5Supl2p3579

Instituto Brasileiro de Geografia e Bioestatística (2019). Cidades e Estados. Recuperado de https://www. ibge.gov.br/cidades-eestados/to.html

Lage, A. P., Roxo, E., Muller, E. E., Poester, F. P., Cavalléro, J. C. M., Ferreira Neto, J. S.,... Gonçalves, V. S. P. (2006). Programa nacional de controle e erradicação da brucelose e da tuberculose (PNCEBT). Brasília, DF: Ministério da Agricultura Pecuária e Abastecimento. 
Lima, P. B., Nascimento, D. L., Almeida, E. C., Pontual, K. A. Q., Amaku, M., Dias, R. A.,... Ferreira Neto, J. S. (2016). Epidemiological situation of bovine tuberculosis in the state of Pernambuco, Brazil. Semina: Ciências Agrárias, 37(5, Suppl. 2), 3601-3610. doi: 5433/1679-0359.2016v37n5Supl2p360 1

Moda, G., Daborn, C. J., Grange, J. M., \& Cosivi, O. (1996). The zoonotic importance of Mycobacterium bovis. Tubercle and Lung Disease, 77(2), 103-108. doi: 10.1016/ S0962-8479(96)90022-2

Néspoli, J. M. B., Negreiros, R. L., Amaku, M., Dias, R. A., Ferreira, F., Telles, E. O.,... Ferreira Neto, J. S. (2016). Epidemiological situation of bovine tuberculosis in the state of Mato Grosso, Brazil. Semina: Ciências Agrárias, 37(5, Suppl. 2), 3589-3600. doi:10.5433/16790359.2016v37n5 Supl2p3589

O'Reilly, L. M., \& Daborn, C. J. (1995). The epidemiology of Mycobacterium bovis infections in animals and man: a review. Tubercle and Lung Disease, 76(Suppl. 176), 1-46. doi: 10.1016/0962-8479(95)90591-X

Pollock, J. M., Rodgers, J. D., Welsh, M. D., \& Mcnair, J. (2006). Pathogenesis of bovine tuberculosis: the role of experimental models of infection. Veterinary Microbiology, 112(2-4), 141-150. doi: 10. 1016/j.vetmic.2005.11.032

Queiroz, M. R., Groff, A. C. M., Silva, N. S., Grisi, J. H. H., Fo., Amaku, M., Dias, R. A.,... Ferreira, F. (2016). Epidemiological status of bovine tuberculosis in the state of Rio Grande do Sul, Brazil. Semina: Ciências Agrárias, 37(5, Suppl. 2), 3647-3658. doi: 5433/1679-0359.2016v37n5Supl2p3647
Ribeiro, L. A., Gonçalves, V. S. P., Francisco, P. F. C., Mota, A. L. A. A., Nascimento, G. T., Licurgo, J. B.,... Borges, J. R. J. (2016). Epidemiological status of bovine tuberculosis in the Federal District of Brazil. Semina: Ciências Agrárias, 37(5, Suppl. 2), 3561-3566. doi: 10.5433/16790359.2016v37n5 Supl2p3561

Rocha, W. V., Jayme, V. S., Mota, A. L. A. A., Brito, W. M. E. D., Pires, G. R. C., Grisi, J. H. H., Fo.,... Gonçalves, V. S. P. (2016). Prevalence and herd-level risk factors of bovine tuberculosis in the State of Goiás, Brazil. Semina: Ciências Agrárias, 37(5, Suppl. 2), 3625-3628. doi: 10.5433/16790359.2016 v37n5Supl2p3625

Secretaria da Agricultura, Pecuária e Aquicultura do Estado de Tocantins (2016). Pecuária. Recuperado de https:// seagro.to.gov.br/pecuaria/

Silva, M. C. P., Gonçalves, V. S. P., Mota, A. L. A. A., Koloda, M., Ferreira Neto, J. S., Grisi, J. H. H, Fo,... Muller, E. E. (2016). Prevalence and herd-level risk factors for bovine tuberculosis in the state of Paraná, Brazil. Semina: Ciências Agrárias, 37(5, Suppl. 2), 3611-3624. doi: 10.5433/16790359.2016v37n5 Supl2 p3611

Thrusfield, M., \& Christley, R. (2018). Veterinary epidemiology. Roboken, NJ: Wiley.

Veloso, F. P., Baumgarten, K. D., Mota, A. L. A. A., Ferreira, F., Ferreira Neto, J. S., Grisi, J. H. H., $F^{\circ}$.,... Gonçalves, V. S. P. (2016). Prevalence and herd-level risk factors of bovine tuberculosis in the State of Santa Catarina, Brazil. Semina: Ciências Agrárias, 37(5, Suppl. 2), 3659-3672. doi: 10.5433/16790359.2016v37n5Supl2p3659 
Vendrame, F. B., Amaku, M., Ferreira, F., Telles, E. O., Grisi, J. H. H., Fo., Gonçalves, V. S. P.,... Dias, R. A. (2016). Epidemiologic characterization of bovine tuberculosis in the State of Rondônia, Brazil. Semina: Ciências Agrárias, 37(5, Suppl. 2), 3639-3646. doi: 5433/1679-0359.2016v37n5Supl2p3639

World Organization for Animal Health (2018). Bovine tuberculosis. In OIE terrestrial manual. Retrieved from https://www. oie.int/fileadmin/Home/eng/Health_ standards/tahm/3.04.06_BOVINE_TB.pdf

World Organization for Animal Health (2019). Infection with Mycobacterium tuberculosis complex. In Terrestrial animal health code. Retrieved from https://www. oie.int/index.php?id=169\&L=0\&htmfile= chapitre_bovine_tuberculosis.htm 
